\title{
Fetal debate continues
}

\section{Washington}

THE US Supreme Court is this month expected to decide a Missouri case that could either reverse or restrict an earlier decision that made abortions legal in the United States. Whatever the outcome, the abortion question will continue to colour scientific research in the United States. The Department of Health and Human Services (HHS) is at present considering extending a federal moratorium on the use of human fetal tissue for transplantation, and in Congress those who see abortion as murder have introduced legislation to regulate the "import, export or transport into or out of any State any human tissue".

Abortion is divisive issue in the United States. Hundreds of thousands of people have converged on Washington at different times this year either to endorse or condemn the Supreme Court's decision in the Roe versus Wade case which, in 1973, established the legal standing of abortion. Even the language of the abortion question is emotionally charged. People who feel abortion is morally wrong want to be called "pro-life", not anti-abortion, whereas those on other side insist they are not pro-abortion, but "pro-choice".

The federal government finds itself in an awkward position in this debate. The Justice Department has joined the state of Missouri in arguing for a change in the Supreme Court's views on abortion, and both Ronald Reagan and now George Bush have aligned themselves with the "pro-life" movement. But at the same time, HHS last year asked the National Institutes of Health (NIH) to address the issue of whether tissue from a legally performed abortion could ethically be used in research. An advisory panel of scientists and ethicists heard testimony on the promise of fetal cells for treatment of diabetes and certain nervous disorders, and on the fear that demand for fetal tissue would start a black market in baby parts.

The panel's report - which reaches the conclusion that so long as abortion is permitted by society, then using fetal tissue with the informed consent of the parents is morally acceptable - is now languishing at HHS. Also buried at the department is a movement, started last year, that would reestablish the HHS Ethics Advisory Board. The board, abandoned since 1979, is necessary before federal funds can be used for research in ethically difficult areas of reproductive medicine such as in vitro fertilization.

At one point late in the Reagan administration, it seemed possible that there would be an executive order banning the use of fetal tissue from induced abortion for research purposes. Although that did not happen, supporters have indicated their willingness to pursue such a move by legislation. Representative Robert Dornan (Republican, California) has introduced the Human Fetal Tissue Transportation Act. The bill would regulate - or in the words of a member of Dornan's staff, "ban" - the interstate transportation of fetal tissue, and would force facilities storing fetal tissue to obtain a federal licence. The bill defines fetal tissue as "any matter yielded by an aborted human pregnancy and any biochemical product derived from such matter".

It is that last part of the definition that spells unexpected trouble for research. If banning transplantation of fetal tissue would slow certain areas of research, banning the use of cell lines derived from human fetuses would be "insane from the point of view of science or humanity", says Stanley Plotkin, a professor at the Wistar Institute in Philadelphia. Fetal cell lines are extremely useful in viral diagnostic laboratories, as many viruses will grow only in fetal cell lines. Fetal cells have also been used to produce a variety of human vaccines, from polio to adenovirus. Merck $\&$ Co. uses a fetal cell line to produce its rubella vaccine. If fetal cells could no longer be used, the FDA would require vaccine manufacturers to obtain new licences for producing their vaccines, a time-consuming and expensive proposition.

Not only does the federal government support research using fetal cell lines, but such cell lines are used by federal laboratories. For example, the Centers for Disease Control in Atlanta maintains stocks of nearly all identified human viruses, and these are frequently stored frozen in human fetal cell lines.

The first human fetal diploid cell line was established in 1960 by Leonard Hayflick and Paul Moorhead, then at the Wistar Institute. The line, dubbed WI-38, was obtained from a Swedish abortion of a female fetus at three-month gestational age. Hayflick, now a professor of anatomy at the University of California, San Francisco, says his work with WI-38 was the first to establish that human cells had a finite lifetime. Populations of WI-38 will divide between 40 and 60 times before the cells lose the ability to divide. This finite lifespan replaced the dogma of the time that any cell grown in culture would transform to become immortal. Hayflick says WI-38 has provided important insights on cellular ageing.

Although the Human Fetal Tissue Transportation Act has only a slim chance of passage, it nevertheless represents one end of the spectrum of concern that the abortion issue has raised, and those supporting Dornan's legislation have exhibited unflagging energy in pursuing their political agenda.

\section{Galileo on its way Washington}

THE orbiter portion of the Galileo spacecraft began its trip to Jupiter last month in mundane fashion by travelling overland from the Jet Propulsion Laboratory in California, where it was built, to Florida, where it is being prepared for launch at the Kennedy Space Center. The atmospheric probe arrived in Florida earlier in the year. After about 10 weeks of testing, the two

\section{Preparing Galileo for launch}

parts will be joined and then set on top of the inertial upper stage booster that will propel Galileo out of Earth orbit.

The space shuttle Atlantis is scheduled to launch Galileo and its booster into Earth orbit on 12 October. Paradoxically, Galileo starts for Jupiter by heading towards the Sun for a rendezvous with Venus. It then returns for two loops around the Earth. The planetary gravity assists will help the inertial upper-stage booster to place the 2.5-tonne spacecraft on a direct trajectory. Arrival at Jupiter is scheduled for December 1995. Joseph Palca

\section{AIDS}

\section{Agency starts work}

Paris

THE French national agency for research on AIDS (ANRS), set up last November under the joint direction of the ministries for Health and for Research, has announced the major themes it has decided to develop. It will give grants to $\mathbf{2 0 2}$ of more than $\mathbf{4 7 0}$ research proposals received. Most (118) will be for basic research, 70 for clinical and epidemiological studies and 24 for public health, human sciences and sociological studies. According to Jean-Paul Lévy, ANRS director, the FF150 million (\$22 million) budget is "realistic" for France even although it may appear small compared to funding in the United States. Peter Coles

\section{Correction}

About 200 French haemophiliacs have developed AIDS (see Nature 339, 87; 1989). 